\title{
Linguistic Hegemony in the EU
}

\author{
Qianqian Jin \\ School of Foreign Languages and cultures, Sichuan University, Chengdu, 610065, China \\ 254478193@qq.com
}

Keywords: Linguistic hegemony, economy, EU multilingualism, culture

\begin{abstract}
The European Union has made tremendous progress in the integration process, especially in the fields of economy. However, language discrepancy in EU seems to be inconsistent with its convergent developing trend of economy and other fields since EU has taken in 27 countries differing in the aspects of culture, languages, religion and ideology. This paper analyses the strong positions of English, German and French in the EU from the perspectives of their history philosophy and theories on European integration, most importantly, the strong economic support of Britain, Germany and France. And the paper tries to propose that linguistic hegemony exists between older capitalist countries and now economically weak countries in the EU.
\end{abstract}

\section{Introduction}

The European Union is one of the most successful examples of regional integration organizations in the current world. Since its establishment in the 1950s, it has always been pursuing the idea of "unity in diversity". It has made tremendous efforts in the deepening of economic and political fields like having the Common Agriculture Policy, realizing the circulation of the Euros and so on. With its enlargement, it faces the problem of dealing with the multilingual situations since its 27 Member states speak 23 languages, which greatly lowers its working efficiency. Some studies on EU multilingualism have come out: Robert Phillipson in his Linguistic Imperialism argues the economic powers of some countries could make them imperialistic in other fields like culture; Edward Said in his book "Culture and Imperialism" proposes the relationship between culture and imperialism. Scholars Such as Li Keyong, Jean Monnet professor Wang Yamei in China also illustrated the inevitability of economic strength and language hegemony within the EU.

Despite their various achievements, there seems to be weak illustrations of the linguistic hegemony existing between older capitalist countries and now economically weak countries in the EU. And this paper tries to propose this point and calls on more attentions given on the multilingualism in the EU.

\section{The language status quo in the $\mathbf{E U}$}

After six rounds of enlargement, the EU has become home for 27 member states housing about 5 million people. Since the EU advocates the equality among member states and cultural diversity, it adopts the multilingualism policy to deal with so many different languages within the member state. And now the number of official languages is 24.According to EU regulations, all 24 languages are supposed to be equal in every aspect. More precisely, each and every citizen is guaranteed the opportunity to address, as well as to receive information from the EU in his or her own language. If we refer to the language use situation within the EU's organizations, we can get a clearer picture: ${ }^{[1]}$ 
Table $1^{[1]}$ : Official and working languages in the EU institutions, advisory bodies and ECB.

Institution or body
European Parliament
Council of the European Union
(Ministers' meetings)
European Commission
Court of Justice
(+ Irish)
Court of Auditors
Economic and Social Committee
Committee of the Regions
European Central Bank

Official languages
All 24 languages
All 24 languages
All 24 languages
All 24 languages

All 24 languages

All 24 languages

All 24 languages

All 24 languages
Working languages

All 24 languages

All 24 languages

English, French, German

French

English, French, German

All 24 languages

All 24 languages

English

1 When Gazzola made this table in 2006, there were only 20 official languages in the EU. I have made some changes on the table since there are currently 24 official languages.

It is obvious that the EU sticks to its principle of multilingualism but keeps English, German and French as the working languages. In the survey "Europeans and their languages" conducted by the European Commission in 2006, English, French and German ranked the first three in both use as mother tongue and use as foreign languages ${ }^{[2]} .{ }^{1}$ According to wikipedia, a working language (also procedural language) is a language that is given a unique legal status in a supra-national company, society, state or other body or organization as its primary means of communication. It is primarily the language of the daily correspondence and conversation, since the organization usually has members with various differing language backgrounds. ${ }^{[3]}$ For most people, to speak of a supra-national organization, the United Nations will come to mind instantly. In the UN, the working languages are Chinese, English, French, Russian Spanish and Arabian. As to why these languages are chosen, the explanation is because these five languages are supposed to have greatly influenced the whole world. In this sense, the languages of the five permanent members of the UN are firstly included. To be specific, English is the language used by America and Britain as well as countries of the British Commonwealth. French of France is used in Europe, Africa, America and Asia. Russian of Russia is widely used in member states of the former Soviet Union and Eastern Europe. Spanish of Spain is the colonial language when Spain colonized many countries and regions in the 15th and 16th century, so Spanish is the official language in countries in Europe, Asia, Africa and America. Besides, Spanish is used by League of Nations---the former state of the UN. As to Chinese, it enjoys the most users in the world. Taking into account of Arabian in the Arabian countries, it is more than suitable to be the working language. ${ }^{[4]}$ So here comes some interesting questions: why should English, French and German stand out as working languages in the EU? What is the point of keeping other official languages since these three function as the working language? Will one of the three (English, for example) or all of them eventually become the official languages?

\section{Historical development of English, German and French}

\section{1 the origins of English, French and German}

If we take a look at the origin of English, it writes: English is a West Germanic language that originated from the Anglo-Frisian dialects brought to Britain by Germanic invaders from various parts of what is now northwest Germany and the Netherlands. Initially, Old English was a diverse group of dialects, reflecting the varied origins of the Anglo-Saxon kingdoms of England. One ofthese dialects, Late West Saxon, eventually came to dominate. ${ }^{[5]}$ In "schools of linguistics", there is a clear illustration of the Indo-European language which puts English and German in the branch of western Germanic and French under the branch of Latin. ${ }^{[6]}$ From this we can see that English, French and

\footnotetext{
${ }^{1}$ [3] http://en.wikipedia.org/wiki/Working language

[4] http://baike.baidu.com/view/4027160.htm

[5] http://en.wikipedia.org/wiki/English_language
} 
German are not the earliest European languages. "European culture is made up of many elements, which have gone through changes over the centuries. Two of these elements are considered to be more enduring and they are: the Greco-Roman element and the Judeo-Christian element." ${ }^{[7]}$ A quick glance at European culture will tell us that Greek and Latin are the earliest ones. But in the EU today, Greek language almost fails to make its voice heard by the world affair. Instead, English, French and German are much more frequently and widely used worldwide. David Crystal in his book "English as a global language" analyzes why English can become a global language and enjoys more popularity than any other language. He concludes that there are two reasons why this happens: First, English is the official language or enjoys the official status in many countries. Second, English dominates foreign language teaching in the rest countries. Even within the EU, English remains the most widely used language, followed by German and French. Compared to the situation in 2001 (EB51.1), the enlargement of the EU has brought Polish and Russian into the list. The level of foreign languages spoken tends to be good, according to the respondents. Considering five most widely used languages spoken as a foreign language, over half of the respondents rate the level of their skills good or very good (English 69\%, Spanish 65\%, German 58\%, French 55\%, Russian 54\%). In all these languages, the estimate of the level of language skills is higher than what was observed in 2001 (EB 54.1). ${ }^{[8]}$ In the history of European integration, France and German suffered much in the Second World War. In French recovery from the war, Jean Monnet was chosen by the then French Foreign Minister Robert Schuman to make recovery plans. Monnet proposed to revitalize French economy by uniting Europe, especially by realizing the cooperation of France and Germany. Monnet's experience convinced him that an effective economic plan can never be made by a single country; instead, it must rely on national cooperation. A workable way to build a union is to find the converging point of interest among different countries to realize wider power. In general countries this could be achieved by sovereign transference: to transfer the agreed part of sovereignty to the union. So a European union can only become possible if a supranational organization could be built so that every country could transfer its right to it. Monnet thought that it should start from the most crucial and the sharpest paradoxical point: after the Second World War, France and German have the deepest conflicts. The focus of their conflicts is the coal in Ruhr and steel in Sarr. Because coal is the raw material for industry, France can benefit if it can have free access to coal. If not, French industry will collapse. And steel is the basic material for revitalizing military power and industry. The common management of coal and steel can not only help France take control of German military and industrial power but also facilitate the European integration. ${ }^{[9]}$ From the origin of the EU, we can see France and German function as two "bigs".In the later development of the EU, France shows its power by pursing "Gaullism". In 1958, De Gaulle established French Fifth Republic. He changed the old way of following the USA in diplomacy and put great emphasis on European integration. By doing this, he succeed in promoting the independence of France and safeguarding France's role in the international affair. For De Gaulle, it is more important to make France the first-class power again than to break the confrontation of the US and the Soviet Union. As to the relationship of France and Europe, there lies a three-layer meaning in his idea: a European union by many countries, an independent Europe under the guidance of France and a big Europe from the Atlantic to Ural. Whichever De Gaulle attached more importance to, France is the centre. So he devoted himself to the construction of a "big Europe". France and German signed "Franco-German Treaty of Friendship and Cooperation" in 1963, which marked the reconciliation of the two countries. After De Gaulle, French leaders still pursed this spirit. The essence of "Gaullism" is to defend French national independence and sovereignty as well as to keep France as a big power. ${ }^{[10] 2}$

\subsection{The Status quo of English, French and Germany}

In the later development of the EU, France almost tries every way to protect French. It is a country that values the language so much that it issued L'Ordonnance de Villers-Cotterêts to proclaim French

\footnotetext{
2 [9] http://big5.ce.cn/gate/big5/intl.ce.cn/gjzx/oz/201007/12/t20100712_21604651.shtml [10] http://www.fabao365.com/news/703694.html

[11] http://en.wikipedia.org/wiki/Base_and_superstructure
} 
as its national language. Its main contents include that Latin should be stopped as an executive language and all papers in the nation should be written in French. But it is not against the use of vernacular languages and only opposes the church to use Latin. Since the French revolution, the country intensified more than ever its regulation on languages. In modern times in the amendment of French Constitution in 1992, words "French is the language of France"appeared and French was protected by Constitution."In 1994,Loi du 4 aofit 1994 relative l'emploi de la langue fanqaise(Literally it means laws on the use of French) was signed and issued by French government and it proved to work well.(Li Keyong,2006:22) Within the affairs of EU, some French leaders give open speech appealing to the world to fight against English hegemony. Some of them react strongly to English when they feel French is threatened. For example, on the EU government's economic summit held in Brussels in 2006, the president of UNICE stared to use English after his French opening. French President Jacques Chirac's face suddenly changed and got so infuriated that he left the hall with his two ministers - Foreign Minister and Finance Minister ${ }^{[11]}$

As to Germany, it faces many challenges since its admission into the EU. According to $\mathrm{Wu}$ Huiping, German is somehow marginalized since the rise of English. The rise of English covers the fields of economy, diplomacy, technology, education, entertainment, sports and so on. English has become a Lingual Franca and the admission of Britain, Ireland and Denmark into the EU in 1973 further intensified its advantageous position. Within the EU, English and French still dominate the EU. Especially the European commission, which boasts of the largest organizational size and the most working staff, prefer to use French and English. Wu Huiping thinks that although German ranks the third most frequently used language in the EU, there is a very big gap among it between French and English. In some negotiations and non formal conferences, simultaneous interpretation of German is even avoided. When Finland and Denmark were the EU revolving presidency countries, its website offered only English, French and local languages. Wu further analyses the barrier to the facilitation of German. She starts from three perspectives: first, there is no agreed language policy in Germany duo to its federalism. Besides, Germans didn't make enough efforts to improve German in the EU compared to France, regardless of the government officials or the common people. Second, Germany is the starter of two world wars. If the government takes political measures to improve German, they would be mistaken by other countries as a signal to start another war. Third, the improvement of German is always trapped by Italian and Spanish, the fourth and fifth languages in the EU. Since small countries like Finland and Denmark see no hope of promoting Finnish and Danish as the Lingual Franca in the EU, they would rather prefer English and French. And if German demands to be the working language, Italian and Spanish will ask for the same treatment. ${ }^{[12]}$

But German is still one of the most powerful languages within the EU. Wu further analyses the natural advantages of German: it enjoys 9.7 million speakers in the EU, much higher than those of French and Spanish. Besides, German is the only official language of Germany and Austria, one of official languages of Luxemburg and Belgium, and a recognized regional language of Italy, France, Denmark, etc. The most important factor might be the economic strength of Germany, which finances the EU most. The pressure of improving German also comes from German economic circle and mass media: documents and papers published in English and French require translation, which cost much money. This is not beneficial to small and medium-sized enterprises in Germany. WU concludes: the essential reason of the German government to promote German is to keep its advantages in the internal market. Also, the improvement of a language cannot be isolated from the identification of common people. The German institute in Mannheim conducted a survey to ask whether it is a good idea to make German the third working language, more than half surveyed agreed and only $15.5 \%$ disagreed. All these push the German government to promote German and the government reacted in an effective way. The former premiere Helmut Kohl urged the president of European commission J.Delors to make German the internal language of the European Commission again since he took office. Other political leaders like the former vice president of European Commission Martin devoted to speaking English in public and Adam Schweizer, the former German foreign minister, proclaimed in 1990: "German should also be the working language besides English and French in the EU." Besides the influence from political leaders, the federal government and parliament also make efforts 
to promote German in the EU. Their combined efforts finally work. In 1993, a publication of the European Commission under Delors stipulates: if the paper is handed within the European Commission, it should be in English, French and German. ${ }^{[12]}$

\section{3 summary}

The above discussion shows that English, French and German manage to stay the first three biggest languages in the EU through ways of globalization, wide frequency of usage and the conscious and desperate efforts its people made to keep their places. A piece of news in 2010 reported that Italy and Spain were irritated by the decision to make English, French and German the official languages in the European Commission. They insisted to add Italian and Spanish. If not, they would rather prefer English as the only one official language. ${ }^{[13]}$ But this proposal met instant oppositions from France and Germany. Although the two countries found this decision to be unacceptable, they did not risk breaking their relationships with France and Germany since they are troubled by economic problems like deficit and national debt. So the economy of a country places a very important role for the government to make decisions. It is obvious that France and Germany hold the most important positions in the EU. And Germany is also compared to an engine of the EU's economy. From the above discussion of the history of European integration it could be seen that France and German were playing the biggest roles. The starting point of European integration is the combination of Germany and France to complete their respective natural resources. It could be said that from the beginning of the EU, other countries had put their trust in France to contend with Germany which started the two world wars. A piece of news on fabao365.com analyses why German economy could stand out in the EU. It writes: according to the statistics by the German Federal Statistics Office, German GDP in 2010 increased by $3.6 \%$ after the regression in 2009, which has surpassed those of many developed countries. The reasons are listed as the advanced system of application scientific research, and improved vocational education system and a stable monetary system. Besides, the big European single market has always been faithfully welcoming products marked by "made by Germany". And Germany did not wait to see this success, German political leaders has made great efforts to this: Germany as an industrialized country realized the formation of a single European market will greatly benefit Germany which is a country relied heavily on exports of industrialized goods. The decision made to pass the establishment of a single market in 1985 and the formal establishment of it in1993 and the later internal market including eastern European countries are all results of the endeavor of German government. ${ }^{[14]}$ Through various efforts, Germany further intensified its economic strength in the EU.

\section{Economic factors behind English, German and French}

In "Das Kapital", Mark claims that the economic basis determines superstructure. To be specific, in Marxist theory, human society consists of two parts: the base and superstructure; the base comprehends the forces and relations of production - employer-employee work conditions, the technical division of labor, and property relations - into which people enter to produce the necessities and amenities of life. These relations determine society's other relationships and ideas, which are described as its superstructure. The superstructure of a society includes its culture, institutions, political power structures, roles, rituals, and state. The base determines (conditions) the superstructure, yet their relation is not strictly causal, because the superstructure often influences the base; the influence of the base, however, predominates. ${ }^{[15]}$ But language does not belong to either the economic basis or superstructure. Obviously language does not belong to the economic basis since language cannot produce material needs for human beings in a direct way. Language is not superstructure either. Language helps human beings form the idea of the world and perceive the whole around them. In the history of western philosophy, people have always been a curious animal. In ancient Greece, they ask questions like what the essence of the world is. Some proposes that it is fire while others claim it to be water. Some argues it to be gold while others hold it to be atoms. The result is people cannot find a convincing answer to this question. This is called ontology by later scholars. In the later history of philosophy, people begin to consider this question in another way, that is, how do we understand this world? This is called epistemology which mainly concerns about three 
questions: what is knowledge? How is knowledge acquired and how do we know what we know? Again the scholars fail to reach an agreement on these questions. Then comes the linguistic turn of philosophy because later it occurs to people that it might be better to ask how we express ourselves so that we can make abstract concepts understood to one another. ${ }^{[16]}$ If we cannot figure this out, how do we communicate with one another? What is the point of the arguments of ontology and epistemology? So the issue of language is of vital importance. Within the EU, Germany and France are the "big powers", they certainly will not forsake their linguistic rights. This might be a reason why France so fervently defends their language and Germany also follows suit. As discussed above, Italy and Spain protested that their languages should enjoy the same rights as German, French and English do. But they still chose not to affect their relationship with the two "bigs" only due to language conflicts. The economic strengths of two "bigs" can never be over exaggerated. In history Spain and Italy used to be "big powers"in the then world. The Invincible Armanda of Spain beat the English fleet in the $16^{\text {th }}$ century and won the maritime hegemony. The fleet plundered many countries and regions to collect fortune. With the accumulation of wealth, Spain soon became a developed capitalist country. As to Italy, it also marches towards a developed country by colonization. But in recent years the two countries suffer from economic crisis and become weaker. So in today's EU, Germany and France have the final say on many affairs within the EU either in a direct or an indirect way.

\section{Conclusion}

English, German and French are the most powerful languages in the EU and the world today. Many reasons have been listed to explain this phenomenon in this paper: the historical origins of the three languages; the rise of Britain, Germany and France as super powers and the economic support of these super powers. Marxism tells us that economic basis determines superstructure. Language, which belongs to neither economic basis nor superstructure, helps us perceive the world and exchange complicated thoughts. Any big power will not relinquish their linguistic right as it is an embodiment of authority. In the EU, countries like Italy and Spain used to be powerful nations by winning maritime hegemony and colonialization. But today they are trapped by national debt and economic crisis. As a result, they forsake their linguistic right to some extent in exchange for economic stability. Within the EU, linguistic hegemony is resulted between Britain, Germany plus France and Italy plus Spain, let alone other smaller and weaker countries like those in Eastern Europe.

\section{Books and References}

[1]. http://ec.europa.eu/education/policy/multilingualism-en

[2]. Europeans and Their Languages. Eurobarometer 63.4. Published in September, 2005

[3]. Liu Runqing, Schools of Western linguistics,[M], Beijing ,Foreign Language Teaching and Research Press, 2002

[4]. Wang Zuoliang, Introduction to European Culture, [M], Beijing,Foreign Language Teaching and Research Press, 2004

[5]. Crystal, David. English as a Global Language. Cambridge: Cambridge University Press, 1997.

[6]. Li Shi'an\&Liu Liyun, History of European integration, [M],Heibei, Heibei people's Press, 2003

[7]. Cao Deming, The European Union from a Cultural Perspective, [M]shanghai: Shanghai Foreign Language Education Press, 2009

[8]. Wu Huiping, Language Policy in Germany, [J],Deutschland-Studied, 2003

[9]. Chen Jiaying, Philosophy of Linguistics ,[M], Beijing: Beijing University Press, 2003

[10]. Li Keyong, "Laws of Protection of French", [J]. Etudes Francaises, 2006

[11]. Wang Yamei, “Characteristics of the EU: on EU's Multilingualism”, [J],Deutschland-Studien, 2010 